\title{
The perfect interdental alternative
}

Do your patients find string floss tricky to use?

Do they find interdental brushes uncomfortable?

Recommend the gentle but effective Waterpik Water Flosser!

This outstanding device uses a combination of water pressure and pulsations to clean deep between the teeth and below the gumline.

The Waterpik Water Flosser is clinically proven to be more effective than traditional brushing and flossing for improving gum health and your patients will find it much quicker and easier to use.

\section{More efficiency and far less mess}

No one likes mess! Intricate tasks are partand-parcel of orthodontics, but clean, clear working can help make the entire treatment process more streamlined.
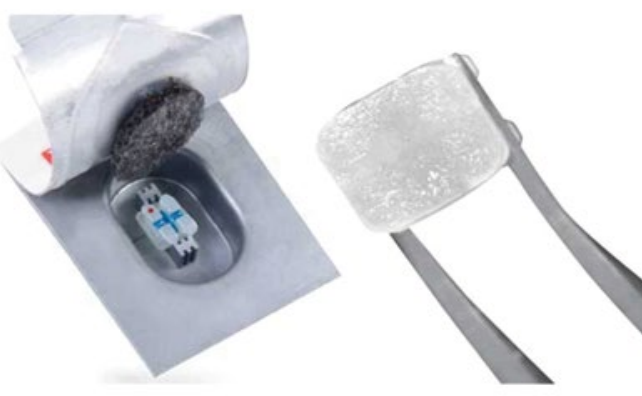

That's where APC Flash-Free Adhesive from 3M Oral Care comes in.

When you are bonding brackets, use this and you will achieve faster treatment times, without any compromise to the end result.

With APC Flash-Free Adhesive, you will still have strength and predictability but with more efficiency and far less mess. There is no need for flash clean-up and the risk of bacterial build-up is significantly reduced.

Work smarter, work cleaner with 3M.

For more information, call 0845873 4066 or visit www. 3 m.co.uk/apcff.

$3 \mathrm{M}$ representatives remain contactable by phone or via video conferencing.

$3 \mathrm{M}$ and APC are trademarks of the 3M Company.
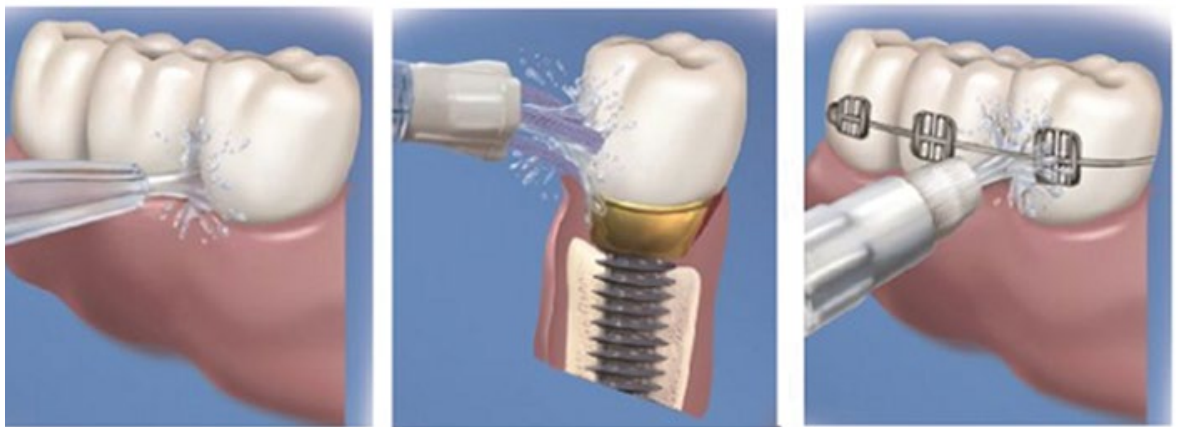

For more information on Waterpik products visit www.waterpik.co.uk. Waterpik products are available from Amazon, Asda, Costco UK, Argos, Boots, Superdrug, online and in stores across the UK and Ireland.
To book a free Waterpik Professional Lunch and Learn - available as a webinar or in-person where it is safe to do so visit www.waterpik.co.uk/professional/ lunch-learn/.

\section{For all your endodontic referrals}

During these trying times, EndoCare can help.

If you have a patient who needs complex endodontic treatment or who suffers from dental phobia or anxiety, by referring to EndoCare you can ensure they will receive the care they need.

The team at EndoCare are all specialists with years of experience and use only the most up-to-date techniques and methods during treatment to ensure the best chances of success. Furthermore,
EndoCare has a real passion for providing as pain-free as possible treatment, which it knows can help put people with anxiety and dental phobia at ease and even help them overcome their fears in the long run.

EndoCare will always return patients to your care with full details of all treatment performed and their suggested next steps.

Find out more by contacting the team today!

For further information call EndoCare on 02072240999 or visit www.endocare.co.uk.

\section{Ground-breaking visualisation}

Revolutionise your workflow with the EXTARO 300 dental microscope, boasting a range of ground-breaking visualisation modes that include:

- Fluorescence Mode - Facilitates caries identification and treatment

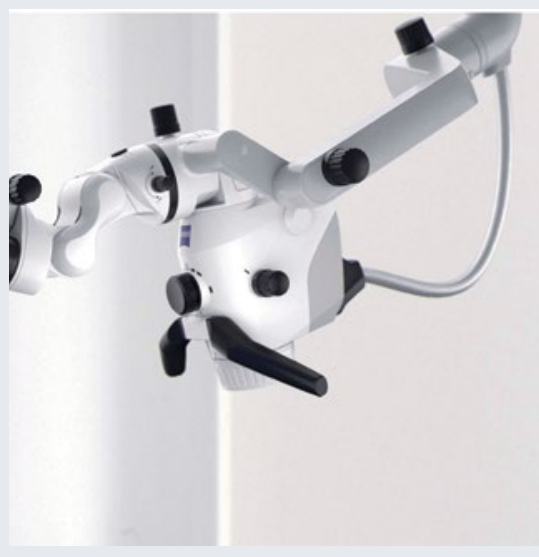

- NoGlare Mode - Enables treatment without distracting reflections and accurate colour shading

- TrueLight Mode - Provides natural, white-light whilst retarding composite curing.

Designed with comfort in mind, the EXTARO 300 also features a Varioskop function and central control that can be used with a single finger to activate the microscope's visual and capture modes. This ensures you can maintain the most ergonomic working position to minimise the risk of strain and fatigue.

Discover the other benefits of the EXTARO 300 by contacting Nuview today.

For more information call Nuview on 01453 872266, email info@nuview-ltd. com or visit www.nuview.co.uk. 